\title{
Proses Penerimaan Diri Istri Pertama yang di Poligami (Studi Kasus di Desa Martadah Kabupaten Tanah Laut)
}

\author{
Laila Wati, Yulia Hairina dan Musfichin \\ Universitas Islam Negeri (UIN) Antasari Banjarmasin
}

\begin{abstract}
This study aims to describe the process of self-acceptance of the first wife who is polygamous where the process of self-acceptance of the four subjects has a different process and time. This study also tries to reveal what factors play an important role in the self-acceptance of the first wife who is polygamous in Martadah village, Tanah Laut district. The type of research carried out is descriptive qualitative research. The subjects are four people with the characteristics of wives who are 40-50 years old. Data collection methods used are interviews and observation. The results showed that the process of self-acceptance of the first wife on the subject was based on her religious understanding, on the other hand the husband had the ability from the material side and the husband was able to be fair and to exercise patience. There are several factors, both internal and external, that play an important role, including self-understanding, realistic expectations, the absence of obstacles in the environment, pleasant attitudes of community members, the absence of emotional disturbances, memories of success, identification with people who are self-adjusted. good behavior, a broad self-perspective, good parenting in childhood, a stable self-concept.
\end{abstract}

Keywords: Self-acceptance, wife, polygamy.

\begin{abstract}
Abstrak
Penelitian ini bertujuan untuk mendeskripsikan proses penerimaan diri istri pertama yang dipoligami dimana proses penerimaan diri dari keempat subjek tersebut tentunya memiliki proses dan waktu yang berbeda-beda. Penelitian ini juga berusaha mengungkap faktor-faktor apa saja yang berperan penting dalam penerimaan diri istri pertama yang dipoligami yang terdapat di desa martadah kabupaten tanah laut Jenis penelitian yang dilakukan adalah penelitian deskriptif kualitatif. Subjek berjumlah empat orang dengan karakteristik istri yang berusia 40-50 tahun. Metode pengumpulan data yang di gunakan adalah wawancara dan observasi. Hasil penelitian menunjukan bahwa proses pengakuan diri pasangan utama mengenai masalah ini tergantung pada persetujuannya yang ketat, di sisi lain suami memiliki kemampuan sejauh materi dan suami mampu bersikap adil serta untuk melatih kesabaran. Terdapat beberapa Faktor -faktor baik internal maupun eksternal yang berperan penting antara lain yaitu pemahaman diri, pengharapan yang realistik, tidak adanya hambatan didalam lingkungan, sikap anggota masyarakat yang menyenangkan, tidak adanya gangguan emosional, kenangan akan keberhasilan, identifikasi dengan orang yang memiliki penyesuaian diri yang baik, adanya perspektif diri yang luas, pola asuh dimasa kecil yang baik, konsep diri yang stabil.
\end{abstract}

Kata kunci: Penerimaan diri; istri; poligami. 
Poligami adalah tindakan perkawinan dengan lebih dari satu pasangan atau pasangan dan merupakan jenis pernikahan yang sampai sekarang ada cukup lama. Islam sendiri pada hakekatnya berpegang pada kerangka perkawinan monologi, dimana seorang suami hanya boleh memiliki satu istri, namun seorang laki-laki boleh saja melakukan perkawinan poligami dengan adanya syarat yang harus dipenuhi bagi seseorang yang ingin menyempurnakannya. Selain itu diperlukan keadilan bagi mereka, baik untuk pengenalan mereka ke dunia (makanan pokok, pakaian sehari-hari) maupun nafkah batin (Jamilah \& Philips Bilal Aminah Abu, 1996).

Jika seorang laki-laki merasa yakin bahwa dia tidak bisa melakukan keadilan kepada anak-anak perempuan yatim, maka carilah perempuan lain (Tihami \& Sohari Sahrani, 2009). Pentingnya pengakuan diri bagi pasangan, khususnya istri utama dengan alasan bahwa efek poligami akan mempengaruhi psikologis yang sebenarnya. poligami yang diusulkan oleh pasangannya sebagian besar merupakan peristiwa traumatis bagi pasangan utama (Sari dkk., 2014).

Adapun faktor-faktor laki-laki yang melakukan poligami, yaitu: dari segi kebutuhan pribadi, yaitu: faktor geografis: iklim dapat menyebabkan wanita lebih cepat tua, faktor menstruasi: wanita cepat menjadi tua di kalangan primitif dan mengalami masa-masa kemalasan karena siklus bulanan dan pasca melahirkan, yang berakibat suami dan istri pada posisi seksual yang berbeda, faktor masa subur: keterbatasan usia produktif wanita dengan memasuki tahap menopouse jumlah wanita lebih banyak dari pria: kelebihan jumlah wanita dibandingkan pria disebabkan beberapa faktor antara lain jumlah kematian pria lebih tinggi dari wanita. Kemandulan seorang wanita: Keinginan untuk memiliki anak adalah sesuatu yang khas dan merupakan kualitas alami yang digerakkan oleh orang-orang. Adapun segi kebutuhan sosialnya, yaitu: faktor ekonomi: laki-laki dengan banyak istri akan memberikan keuntungan seperti menjadikan istri sebagai pekerja/budak dan menjualnya untuk kebutuhan hidup, jumlah anak dan faktor identitas: minat untuk membangun jumlah kerabat untuk memperluas jumlah anggota keluarga. Perempuan lebih banyak dari pada laki-laki: banyaknya jumlah perempuan dibandingkan laki-laki disebabkan oleh beberapa hal, antara lain jumlah 
kematian laki-laki lebih tinggi dari perempuan, menjauhkan diri dari anak-anak yang dikandung secara tidak sah: poligami diandalkan untuk menghapus anak-anak yang dibawa ke dunia tanpa ikatan perkawinan (Sembiring, 2007).

Adapun hikmah diizinkannya berpoligami (dalam keadaan darurat dengan syarat berlaku adil) mencakup hal-hal berikut: untuk menciptakan keturunan bagi pasangan yang subur dan istri yang kesepian, untuk menjaga kehormatan keluarga tanpa berpisah dari istri, meskipun istri tidak dapat melakukan pekerjaannya sebagai seorang istri, atau dia memiliki ketidakmampuan. atau sekali lagi penyakit serius, untuk menyelamatkan dari hiperseks dari perselingkuhan dan keadaan darurat moral lainnya, untuk menyelamatkan wanita dari keadaan darurat moral yang hidup di negara atau masyarakat di mana jumlah wanita jauh lebih menonjol daripada pria. Misalnya, karena konflik yang panjang (Ghozali, 2010).

Berdasarkan paparan yang dijelaskan, Fenomena yang menarik dari adanya poligami adalah terdapat beberapa keluarga yang memilih untuk menempatkan istri-istrinya dalam satu rumah yang sama, kenyataan ini akan menjadi tantangan tersendiri bagi istri yang dipoligami karena harus bisa menerima kenyataan selain suaminya menikah lagi tetapi juga menempatkan istri yang lainnya dalam satu rumah dengan dirinya, seperti halnya yang terjadi di Desa Martadah. Maka dari itu peneliti tertarik untuk meneliti tentang proses penerimaan diri istri pertama yang di poligami di desa Martadah kabupaten Tanah laut dengan judul "proses penerimaan diri istri pertama yang dipoligami ( studi kasus di desa Martada Kabupaten Tanah laut)". Tujuan penelitian ini adalah untuk mengetahui proses penerimaan diri istri pertama yang dipoligami yang terjadi di desa Martadah kabupaten Tanah laut Kemudian untuk mengetahui faktor-faktor apa saja yang berperan penting dalam penerimaan diri istri pertama yang dipoligami yang terjadi didesa Martadah kabupaten Tanah laut.

Penerimaan diri (self-acceptance) menurut kamus lengkap psikologi adalah sikap yang pada dasarnya merasa puas dengan dirinya, kualitas-kualitas dan kemampuan diri sendiri, dan pengakuan terhadap keterbatasan-keterbatasan sendiri (Chaplin, 2006). Selain itu poligami pun terkait dengan penerimaan diri, adanya penerimaan diri akan membantu individu untuk dapat berfungsi secara ideal sehingga individu dapat mengembangkan segala kemampuan dan 
potensi yang dimiliki dengan optimal. Individu yang memiliki pengakuan diri yang luar biasa akan lebih siap untuk bertahan dan mengubah kondisi emosional mereka ke kebenaran yang mereka hadapi (Fajar, 2020).

Kebanyakan hubungan poligami dilakukan secara siri karena tidak sedikit wanita yang setuju dengan hubungan poligami, banyak wanita menolak poligami dalam keluarga mereka karena berbagai alasan yang mereka akui. Namun, ada juga beberapa wanita yang bisa mengakui kemungkinan poligami dikeluarga mereka. Alasan pasangan harus berpoligami adalah ketergantungan keuangan dan persyaratan untuk pertimbangan dari pasangannya. Demikian juga, pasangan memiliki ketakutan akan rasa malu yang luar biasa dari masyarakat dengan asumsi mereka berpisah dan membutuhkan bantuan suami dalam membesarkan anakanak (Sari dkk., 2014).

Berdasarkan paparan yang dijelaskan, maka peneliti tertarik untuk meneliti tentang proses penerimaan diri istri pertama yang di poligami di desa Martadah kabupaten Tanah laut dengan judul "proses penerimaan diri istri pertama yang dipoligami (studi kasus di desa Martadah kabupaten Tanah laut)". Tujuan penelitian ini adalah untuk mengetahui proses penerimaan diri istri pertama yang dipoligami yang terjadi di desa Martadah kabupaten Tanah laut. Kemudian untuk mengetahui faktor-faktor apa saja yang berperan penting dalam penerimaan diri istri pertama yang dipoligami yang terjadi didesa Martadah kabupaten Tanah laut.

\section{Metode}

Jenis penelitian ini adalah penelitian deskriptif kualitatif. Pemilihan subjek menggunakan metode purposive sampling, yaitu berdasarkan ciri dimiliki subjek yang dipilih, seperti istri pertama yang dipoligami (Herdiansyah, 2015). Objek penelitian ini adalah proses penerimaan diri istri pertama yang dipoligami dan faktor-faktor apa saja yang berperan penting dalam penerimaan diri istri pertama yang dipoligami yang terdapat di desa Martadah Kecamatan Tambang Ulang Kabupaten Tanah Laut, Subjeknya adalah para istri pertama yang menerima dipoligami sebanyak empat orang. Kreteria yang dijadikan subjek penelitian adalah 
istri pertama yang menerima dipoligami di desa Martadah Kecamatan Tambang Ulang Kabupaten Tanah Laut, yang berumur 40-50 tahun, teknik pengumpulan data, pengumpulan data dalam penelitian ini dimaksudkan untuk memperoleh memperoleh bahan-bahan, keterangan, kenyataan-kenyataan dan informasi yang dapat dipercaya. Untuk memperoleh data seperti yang dimaksudkan itu, dalam penelitian digunakan teknik-teknik, prosuderprosuder, alat-alat, serta kegiatan yang nyata. Selain menggunakan wawancara, penelitian ini juga menggunakan metode observasi sebagai pendukung hasil wawancara untuk penelitian (Basrowi \& Suwandi, 2008).

Faktor-faktor yang mempengaruhi penerimaan diri menurut teori Hurlock, ada beberapa faktor-faktor atau kondisi yang mempengaruhi penerimaan diri individu, antara lain: pemahaman diri, pengharapan yang realistik, tidak ada penghalang didalam lingkungan, sikap anggota masyarakat yang menyenangkan, tidak adanya gangguan emosional, kenangan akan keberhasilan, identifikasi dengan orang yang memiliki penyesuaian diri yang baik, adanya perspektif diri yang luas, pola asuh dimasa kecil yang baik, konsep diri yang stabil (Ardilla, 2013).

\section{Hasil}

Berdasarkan hasil penelitian yang didapat oleh peneliti, bahwasanya penelitian ini memiliki empat orang subjek sebagai sampel dari keluarga berpoligami di desa Martadah, keempat subjek ini adalah istri pertama yaitu wanita dipoligami yang tinggal didesa Martadah, yang berinisial M, HS, MS, dan AS. Dari hasil wawancara penelitian dengan para subjek penelitian, informasi yang di peroleh terkait dengan masalah pernikahan poligami cukup bervariasi. Pertama, ketika ditanyakan pandangan terhadap keluarga poligami, menurut subjek M pernikahan yang baik itu bukan masalah poligaminya tapi tergantung pada diri seseorang, subjek MS dan AS ternyata juga memiliki pendapat yang serupa tentang poligami, bahwasanya keluarga yang baik itu tidak tergantung suami berpoligami atau tidak, menurut subjek MS dan AS keluarga yang baik itu yang terpenting jujur satu sama lain, saling mendengarkan dengan penuh perhatian, saling yakin, dan saling memberi waktu luang untuk pasangan, namun 
berbeda dengan pendapat subjek HS yang mengatakan pernikahan yang baik itu hanya memiliki satu istri tidak lebih kecuali dalam kebaikan agama. Kedua, tentang bagaimana poligami di mata mereka, semua subjek memiliki pendapat yang sama mengatakan bahwa poligami itu hukumnya sah-sah saja bahkan sunnah, menurut semua subjek, hal ini yang kemudian menjadi salah satu faktor kenapa mereka menerima pernikahan poligami, karena yang mereka ketahui poligami itu tidak dilarang ataupun haram, menurut mereka pernikahan yang baik itu tergantung dari diri dan sudut pandang masing-masing bukan masalah poligaminya.

Istri yang bersedia dipoligami dapat dikatakan perlu adanya sebuah penerimaan diri, Adanya penerimaan diri akan membantu individu untuk dapat berfungsi secara ideal sehingga individu dapat mengembangkan segala kemampuan dan potensi yang dimiliki dengan optimal. Penerimaan diri dari keempat subjek yaitu istri pertama tentunya memiliki proses dan waktu yang bervariasi. Berdasarkan hasil wawancara dan observasi yang dilakukan kepada para subjek. Subjek HS dan MS menunjukan reaksi kecewa diawal mengetahui suami menikah lagi.Namun berjalannya waktu rasa kecewa itu berkurang tentunya dengan usaha yang subjek HS dan MS lakukan agar rasa kecewa itu berkurang, usaha subjek HS yaitu dengan cara bekerja sampingan seperti bekerja serabutan misalnya menjaga anak warga, mencuci pakaian orang, sedangkan usaha subjek MS yaitu pedagang didepan rumah. Penerimaan diri keempat subjek didorong oleh keinginan sendiri, tanpa ada paksaan dorongan orang lain atau tanpa adanya paksaan yang mengharuskan mereka menerima untuk dipoligami. Dimana semua subjek sebelum menemukan penerimaan diri dalam berpoligami subjek tidak lepas dari tahapan-tahapan perjalanan hidup yang dijalani. Mulai dari bagaimana penerimaan diri itu muncul, proses penerimaan diri, hingga akhirnya penerimaan diri tersebut mampu membuat subjek menerima dipoligami. Proses penerimaan diri mereka di lakukan dengan memasrahkan hati semata-mata hanya karena Tuhan, dan suami memiliki kemampuan dari sisi materi, dan suami mampu bersikap adil. Salah satu hal yang dapat melatih kesabaran pada masing-masing subjek adalah dengan menghadapi kondisi poligami. Subjek tidak menyangka semuanya akan terjadi karena subjek sangat lama mengenali suaminya. Sekarang, tidak ada lagi perasaan marah dan cemburu dan dengki dalam hati subjek, hubungan subjek dengan keluarga suami 
subjek dan keluarga istri muda subjek sangat baik. Seperti apa yang diungkapkan oleh HS yang mengatakan dengan usaha yang sabar dan ikhlas, banyak rintangan yang harus dilalui hingga sekarang, dengan kesabaran hatinya untuk menerima suaminya menikah lagi. Begitupun dengan subjek yang lain, proses menerima diri dipenuhi dengan suka dan duka. Subjek MS mengatakan duka dalam pernikahan poligami yaitu dampak ke anak, karena tidak tega (kasihan) melihat anak, sukanya MS mengatakan tidak terlalu repot mengurus suaminya karena ada yang mengurus suami selain dia. Begitu juga dengan subjek AS pernikahan poligami memang membawa perubahan, misalnya ketika menikah lagi mengalami penurunan tabungan tiap bulannya, karena mau tidak mau ia harus berbagi.

Proses pengenalan diri pada setiap subjek dimulai dari memahami karakteristik dan kekurangan diri sendiri. masing-masing dari keempat subjek sama-sama dirasa kurang yang dimiliki dari diri mereka sebagai istri yang mungkin pada akhirnya membuat suami mencari istri yang lain (Prasetia, 2013). Semua subjek ada yang menilai dan memberikan penilaian terhadap dirinya masing-masing, Subjek M menilai bahwa dirinya lebih baik, karena subjek M dapat menerima dengan ikhlas, dan subjek $M$ sendiri yang melamar istri kedua untuk suaminya. Subjek HS menilai bahwa dirinya cenderung untuk mudah cemburu terhadap istri lain. Subjek MS menilai bahwa suaminya tidak miliknya sendiri, dan menerima dengan sabar dan ikhlas, kesabaran dan ikhlasnya kembali ketauhid, ilmu agama dan guru-guru yang memberikan nasehat agama. Sedangkan subjek AS mengharapkan memiliki keluarga yang sakinah untuk pasangan dan anak-anaknya yang lebih baik serta untuk keluarga yang lebih jauh (pasangan yang berbeda) dengan saling menghormati dan mengajarkan satu sama lain, menganggap kakak beradik. Subjek M, MS dan AS mengatakan pernikahan yang baik itu bukan masalah poligaminya tetapi tergantung pada diri seseorang. Berbeda halnya dengan subjek HS yang mengatakan pernikahan yang baik itu pernikahan yang hanya memiliki satu istri, tidak lebih kecuali dalam kebaikan agama dan bisa berbuat adil. Awal mula subjek HS sulit menerima dan tidak percaya, karena subjek sangat mengenal sifat suaminya. Seiring berjalannya waktu subjek HS memberikan ijin suaminya untuk berpoligami, karena subjek HS ingin melihat suaminya bahagia. 
Proses penerimaan diri mereka kemudian dilakukan dengan menyerah begitu saja karena Allah, dan pasangan memiliki kapasitas dari sisi materi, dan pasangan dapat bertindak secara normal. Hal yang dapat mempersiapkan kegigihan pada masing-masing subjek adalah menghadapi kondisi poligami. Subjek HS, MS dan sujek AS tidak menyangka semuanya akan terjadi karena subjek sudah cukup lama mengenal pasangannya. Saat ini sudah tidak ada lagi rasa amarah dan keinginan serta kecemburuan di hati subjek, hubungan subjek dengan keluarga setengah baik subjek dan keluarga pasangan muda subjek sangat baik.

Begitupun dengan halnya subjek MS, subjek MS tidak mau kalau suaminya sering bertemu yang tidak jelas dengan wanita lain, dan subjek MS juga merasa kalau suaminya bukan miliknya sendiri, dan MS juga merasa kalau masalah ekonomi tercukupi saja, dan subjek MS juga melatih keikhlasan dan kesabarannya kembali ke tauhid, ilmu agama, dan ke guruguru dan meyakini bahwa poligami dibolehkan dalam agama. Cara subjek bersikap tenang dan tenang dalam keadaan poligami yang dia hadapi adalah terus mendekat kepada Tuhan Yang Maha Kuasa. Akhirnya, subjek itu menghargai bahwa ajakannya diizinkan, saat ini subjeknya lebih gigih dengan segala sesuatu.

Memang, sulit bagi pasangan untuk mengakui suaminya menikah lagi, namun dengan siklus keempat istri berusaha untuk mengakui cara mereka berpoligami. Keempat subjek memahami bahwa menjadi tragis, marah, dan bingung bukanlah rencana keluar untuk mengurus masalah ini. Adapun faktor-faktor yang berperan penting dalam penerimaan diri istri pertama yang dipoligami, penerimaan diri pada setiap individu dipengaruhi beberapa faktor antara lain: pemahaman diri, pengharapan yang realistik, tidak adanya hambatan didalam lingkungan, sikap anggota masyarakat yang menyenangkan, tidak adanya gangguan emosional, kenangan akan keberhasilan, identifikasi dengan orang yang memiliki penyesuaian diri yang baik, adanya perspektif diri yang luas, pola asuh dimasa kecil yang baik, konsep diri yang stabil, yang mana dapat diklasifikasikan menjadi dua faktor, faktor internal dan faktor eksternal. faktor internal adalah faktor yang berasal dari dalam diri individu sendiri, dari hasil wawancara peneliti kepada setiap subjek, yaitu pemahaman diri, pengharapan yang realistik, tidak memperhatikan kejengkelan yang menggebu-gebu, ingatan akan pencapaian, masa kanak-kanak yang hebat, gagasan diri yang stabil, faktor eksternal adalah faktor yang berasal 
dari luar individu sendiri, yaitu tidak adanya hambatan dalam lingkungan, sikap anggota masyarakat yang menyenangkan, identifikasi dengan orang yang memiliki penyesuaian diri yang baik, adanya persfektif diri yang luas.

Keempat subjek dapat dikatakan telah mencapai pengakuan diri. Bagaimanapun, pengakuan diri di antara keempatnya memiliki penggambaran dan interaksi pengganti. Pengakuan diri M, HS, MS, AS dibentuk oleh pemahaman diri yang besar, ide diri yang stabil, dan dukungan dan energi dari pasangan dan keluarga yang dikenang untuk pandangan yang mengangkat. MS bisa memahami bahwa suaminya bukan milik dirinya sendiri, begitu juga dengan subjek M yang tidak mau suaminya berperilaku yang membuat keluarga malu, bahkan yang melamar untuk dijadikan istri kedua dari suaminya itu subjek $\mathrm{M}$ sendiri, sama halnya dengan subjek AS tidak ingin membuat keluarga malu, dan HS juga menerima suaminya menikah lagi karena ingin membahagiakan suaminya.

Pemahaman diri dari keempat subjek tersebut dapat dibentuk berdasarkan fakta bahwa mereka akan mengakui dengan sungguh-sungguh dan berusaha untuk tidak terlibat dalam masalah yang dihadapi. Adanya hal yang realistik membuat hal ini timbul jika individu menentukan sendiri harapannya dengan disesuaikan dengan pemahaman dan kemampuannya, dan bukan diarahkan oleh orang lain dalam mencapai tujuannya, dengan memiliki harapan yang realistik, maka akan semakin besar kesempatan tercapainya harapan itu, dan hal ini akan menimbulkan kepuasan diri yang merupakan hal penting dalam penerimaan diri. Hal ini terdapat dengan subjek HS, sebuah harapan yang dia inginkan hanyalah mengharapkan ridha Allah Swt.

Meskipun seseorang saat ini memiliki asumsi praktis, jika iklim umum tidak memberikan celah atau penghalang, maka, pada saat itu, asumsi individu akan sulit untuk dipenuhi. Faktor lingkungan dalam hal ini, tetangga secara tidak langsung memberikan dampak positif/negatif bagi semua subjek yang berpoligami atau di poligami, dan dampak yang diberikan oleh lingkungan sekitar (tetangga) adalah dampak positif. Keempat subjek Merasa pasangan dan keluarganya secara konsisten menunjukkan perspektif yang menggembirakan terhadap diri mereka sendiri, mereka memberikan perenungan dan beberapa solusi untuk keempat subjek dalam menangani kepentingan mereka. Sehingga semua subjek 
tidak merasakan hambatan dalam iklim umum. Selain itu, pandangan yang baik dari orangorang dari daerah tersebut juga tidak menimbulkan bias, karena ada kepedulian pada kapasitas sosial orang lain dan keinginan individu untuk mengikuti kecenderungan alam. Begitupun sikap-sikap semua subjek baik-baik saja.

Dalam konteks berpoligami atau dipoligami semua subjek tidak memiliki tekanan emosional yang berlebihan, dikarenakan semua subjek memiliki pemikiran atau tindakan yang sudah dewasa (mengerti apa itu poligami), karena mereka berpikir tekanan emosi sekecil apapun dapat mengganggu keseimbangan individu itu sendiri, salah satunya stres, stres menggambarkan adanya kondisi yang tidak seimbang dalam diri individu. Keberhasilan M dalam membantu proses poligami suaminya dengan istri kedua, merupakan suatu pencapaian yang dimaksudkan kepadanya, kemudian, pada saat itu, mendukung $\mathrm{M}$ dalam sensasi persetujuan yang luar biasa. Ini adalah kemenangan yang telah terjadi pada $\mathrm{M}$ yang akan menyebabkan M memiliki pengakuan diri yang positif. Individu yang memiliki penyesuaian diri yang baik akan dapat membangun sikap-sikap yang positif terhadap diri sendiri, dan bertingkah laku dengan baik yang menimbulkan penilaian diri yang baik. Penyesuaian diri MS yaitu dengan cara bersosialisasi di masyarakat dengan mengikuti majelis ta'lim, hal tersebut secara tidak langsung membuat kepribadian MS menjadi lebih baik. Dengan kehadiran sudut pandang yang luas tentang diri sendiri dan perspektif orang lain semua subjek dapat belajar dari pengalaman orang lain tersebut.

Faktor-faktor yang mempengaruhi penerimaan diri menurut hurlock, pemahaman diri, harapan yang realistis, tidak adanya hambatan lingkungan, tingkah laku sosial yang sesuai, tidak adanya stress emosional, kenangan akan keberhasilan, identifikasi dengan orang yang memiliki penyesuaian diri yang baik, adanya perspektif diri yang luas, pola asuh dimasa kecil yang baik, konsep diri yang stabil. Soal HS, faktor yang cukup sering berperan dalam pengakuan diri adalah cita-cita yang masuk akal seperti keinginan masuk surga yang dijunjung dengan kesepakatan yang ketat.

Faktor-faktor yang dianggap memiliki peranan penting dalam informasi diri yang ada pada mata pelajaran hasil belajar hanyalah pemahaman tentang mata pelajaran yang 
sebenarnya, perspektif individu daerah setempat yang baik-baik saja. Seperti halnya dengan subjek AS mengatakan kalau subjek AS tidak dipoligami belum tentu kehidupannya akan lebih baik seperti ini, sama halnya dengan seperti yang dikatakan suami subjek $M$, menurutnya semua berasal dari hati, ada jalan-jalan di taman monogami atau poligami. Orang penting subjek M mengatakan bahwa ia telah menjalani poligami dengan dua pasangan di rumah yang sama selama sebelas tahun terakhir, menurut cerita, hal utama dalam keluarga poligami adalah pengakuan diri kepada istri.

\section{Kesimpulan}

Berdasarkan uraian yang telah peneliti gambarkan dalam pembahasan sebelumnya, maka dapat peneliti simpulkan, yang sesuai dengan rumusan masalah yaitu bagaimana proses penerimaan diri istri pertama yang dipoligami yang terdapat di desa Martadah dan faktorfaktor apa saja yang berperan penting dalam penerimaan diri istri pertama yang dipoligami yang terdapat di desa Martadah. Kesimpulan yang diperoleh dari penelitian yaitu sebagai berikut:

Penerimaan diri dari keempat subjek yaitu istri pertama tentunya memiliki proses dan waktu yang bervariasi. Para subjek menunjukan reaksi kecewa di awal mengetahui suami menikah lagi. Namun berjalannya waktu rasa kecewa itu berkurang tentunya dengan usaha yang mereka lakukan. Secara umum penerimaan diri keempat subjek didorong oleh keinginan sendiri, tanpa ada paksaan dorongan orang lain atau tanpa adanya paksaan yang mengharuskan mereka menerima untuk dipoligami. Dimana semua subjek sebelum menemukan penerimaan diri dalam berpoligami subjek tidak lepas dari tahapan-tahapan perjalanan hidup yang dijalani. Dimulai dari mengenali kelebihan dan kekurangan diri yang dimiliki sebagai istri. Setelah itu proses penerimaan diri mereka dilakukan dengan memasrahkan hati semata-mata hanya karena Tuhan, lagi pula disisi lain suami memiliki kemampuan dari sisi materi, dan suami dapat berperilaku wajar dalam hubungan poligami selesai. Hal yang dapat mempersiapkan kegigihan dalam setiap mata pelajaran adalah menghadapi kondisi poligami. 
Adapun faktor-faktor yang berperan penting dalam pengakuan diri istri pertama yang dipoligami yang terdapat di desa Martadah secara umum terbagi menjadi dua, yaitu faktor internal dan faktor eksternal. Untuk faktor internal, termasuk pemahaman diri, pemahaman diri yang ada pada kesemua subjek, dapat dibentuk karena mereka mampu mengakui dengan sungguh-sungguh dan melakukan apa saja agar tidak terpecah belah dalam masalah tersebut. Pengharap yang realistik hal ini terdapat dengan subjek HS, sebuah harapan yang dia inginkan hanyalah mengharapkan ridha Allah Swt. Kenangan akan keberhasilan, dalam hal ini keberhasilan M dalam membantu proses poligami suaminya dengan istri kedua, merupakan suatu pencapaian penting baginya, karena itu mendukung $\mathrm{M}$ dalam perasaan yang sangat tentram. Hal ini akan membuat $\mathrm{M}$ memiliki penerimaan diri yang positif. Pengasuhan hebat dimasa muda, gagasan diri yang stabil, sikap-sikap semua subjek baik-baik saja artinya tidak adanya gangguan emosional.

Sedangkan faktor eksternal, yaitu subjek tidak merasa ada hambatan di lingkungan sekitarnya, keempat subjek merasa bahwa suami dan keluarga mereka menunjukkan perspektif yang menggembirakan terhadap diri mereka sendiri, mereka memberikan pertimbangan dan beberapa jawaban untuk empat mata pelajaran dalam menghadapi masalah mereka. Warga negara yang baik juga tidak menimbulkan bias, mengingat kapasitas sosial orang lain dan aksesibilitas individu untuk mengikuti kecenderungan reguler. ID dengan individu serbaguna. MS yaitu dengan cara bersosialisasi di masyarakat dengan mengikuti majelis ta'lim, hal tersebut secara tidak langsung membuat kepribadian MS menjadi lebih baik. Adanya perspektif diri yang luas dan pandangan dari orang lain, semua subjek dapat belajar dari pengalaman orang lain tersebut.

Saran

Dari hasil penelitian yang telah dilaksanakan, peneliti menyadari masih terdapat kekurangan pada penelitian ini. Oleh sebab itu, saran yang peneliti berikan ini dapat dijadikan sebagai bahan pertimbangan untuk penyempurna peneliti selanjutnya yang nantinya akan melakukan penelitian terkait dengan proses penerimaan diri istri pertama yang dipoligami (Studi Kasus di Desa Martadah Kecamatan Tambang Ulang), yaitu: untuk tambahan ilmuwan, dipercaya dapat memimpin pemeriksaan lain dengan topik poligami menurut perspektif lain, 
misalnya menurut perspektif suami yang melakukan poligami atau anak-anak yang berlatar belakang poligami.

\section{Referensi}

Ardilla, F. (2013). Penerimaan Diri pada Narapidana Wanita. Jurnal Psikologi Kepribadian dan Sosial, 2(1), 3.

Basrowi, \& Suwandi. (2008). Memahami Penelitian Kualitatif. Rineka Cipta.

Chaplin, J. P. (2006). Kamus Lengkap Psikologi (Kartini Kartono, Penerj.). PT. Rajagrafindo Persada.

Fajar, M. (2020). Kebahagian Pada Istri yang di Poligami [Skripsi]. Fakultas Psikologi Universitas Muhammadiyah Surakarta.

Ghozali, A. R. (2010). Fiqih Munakahat. Kencana Prenada Media Group.

Herdiansyah, H. (2015). Metodologi Penelitian Kualitatif untuk Ilmu Psikologi. Salemba Humanika.

Jamilah, J., \& Philips Bilal Aminah Abu. (1996). Monogami dan Poligini Dalam Islam. PT. Rajagrafindo Persada.

Prasetia, W. D. (2013). Hubungan Penerimaan Diri dengan Rasa Percaya Diri Pada Siswa Kelas X SMAN 1 Grati Pasuruan [Skripsi]. Fakultas Psikologi Universitas Islam Negeri Maulana Malik Ibrahim Malang.

Sari, A., Yeniar Indriana, \& Nailul Fauziah. (2014). Penerimaan Diri Terhadap Poligami pada Istri Pertama. Jurnal Empati, 3(2), 2-3.

Sembiring, I. A. (2007). Berbagai Faktor Penyebab Poligami dikalangan Pelaku Poligami. Jurnal equality, 12(2), 115.

Tihami \& Sohari Sahrani. (2009). Fikih Munakahat. Rajagrafindo Persada.

\begin{tabular}{|c|l|l|l|c|}
\hline \multicolumn{1}{|c|}{ Submit } & \multicolumn{1}{|c|}{ Review } & Revisi & Diterima & Publish \\
\hline 07-12- 2021 & $03-01-2022$ & $09-01-2021$ & $10-01-2021$ & $04-02-2022$ \\
\hline
\end{tabular}

\section{Laila Wati, Yulia Hairina, Musfichin \\ Program Studi Psikologi Islam \\ Fakultas Ushuluddin dan Humaniora \\ Universitas Islam Negeri (UIN) Antasari Banjarmasin}

E-mail: lailawati0709@gmail.com 